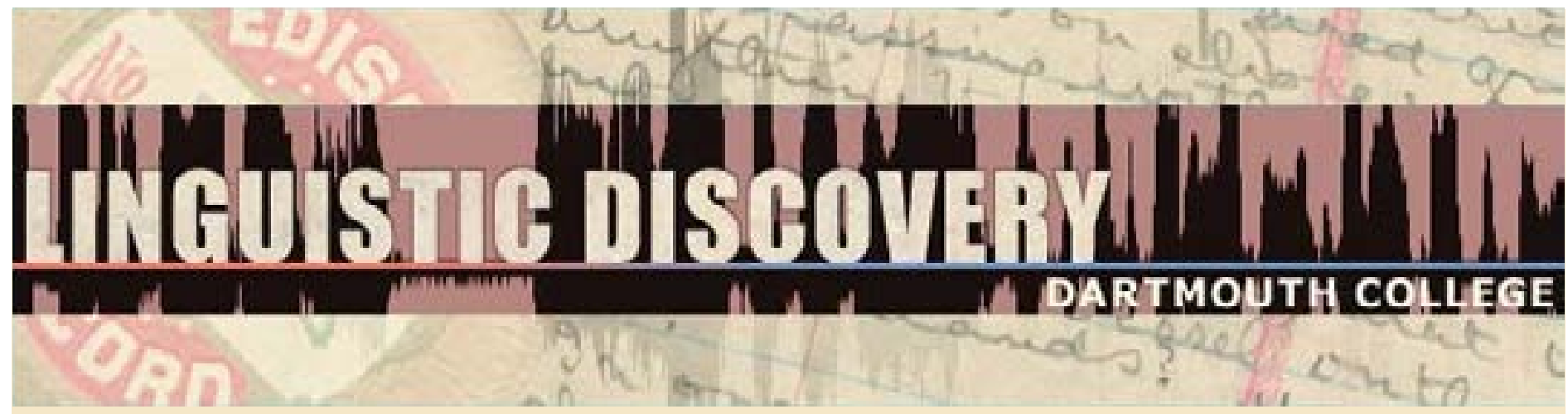

Volume 8 Issue 1 2010

\section{Semantic Maps as Metrics on Meaning}

\section{Michael Cysouw}

Max Planck Institute for Evolutionary Anthropology, Leipzig

doi: 10.1349/PS1.1537-0852.A.346

url: http://journals.dartmouth.edu/cgi-bin/WebObjects/ Journals.woa/1/xmlpage/1/article/346 


\section{Semantic Maps as Metrics on Meaning \\ Michael Cysouw \\ Max Planck Institute for Evolutionary Anthropology, Leipzig}

By using the world's linguistic diversity, the study of meaning can be transformed from an introspective inquiry into a subject of empirical investigation. For this to be possible, the notion of meaning has to be operationalized by defining the meaning of an expression as the collection of all contexts in which the expression can be used. Under this definition, meaning can be empirically investigated by sampling contexts. A semantic map is a technique to show the relations between such sampled contextual occurrences. Or, formulated more technically, a semantic map is a visualization of a metric on contexts sampled to represent a domain of meaning. Or, put more succinctly, a semantic map is a metric on meaning.

To establish such a metric, a notion of (dis)similarity is needed. The similarity between two meanings can be empirically investigated by looking at their encoding in many different languages. The more similar these encodings, in language after language, the more similar the contexts. So, to investigate the similarity between two contextualized meanings, only judgments about the similarity between expressions within the structure of individual languages are needed. As an example of this approach, data on cross-linguistic variation in inchoative/causative alternations from Haspelmath (1993) is reanalyzed.

\section{Measuring Meaning}

Meaning is a particularly elusive property to measure. The central problem is that the meanings of linguistic expressions are variable across languages, and it is still mostly unknown how large this variability is. It does not really help to analyze the meaning of a language-specific expression (for example the English verb to walk) by saying that it expresses a general concept (like WALK). Such a change in typography still leaves open the question as to what the relation is between WALK and, for example, the meaning of the German word spazieren or the Spanish word andar. Actually, without a more explicit definition of the concept WALK, asking whether andar expresses the concept WALK is not much different from asking whether andar means the same as to walk. Yet, individual linguistic expressions across languages never convey exactly the same range of senses, making such a simplistic approach to comparing meaning across languages devoid of content.

In this paper, I will defend the view that a much more profitable operationalization of crosslinguistic variability of meaning is achieved by defining the meaning of a language-specific expression as the collection of all contexts in which the expression can be used. This definition represents, to some extent, a reversal of the intuitive notion of meaning. Meaning is typically thought of as some kind of property of a linguistic expression that governs its potential appearance in a particular context. In this conventional view, the main difficulty is how to express this property called "meaning". The approach to meaning proposed in this paper simply defines this property as the sum of all actual appearances. It is of course practically impossible to ever collect all appearances of a particular linguistic expression (be it a lexical or a grammatical item) in a living language - though this is possible for a dead language by including all documentation available - but samples of contexts can be used for any empirical question at hand (cf. Croft 2007; Wälchli \& Cysouw 2008 for a similar approach to meaning).

Samples of the actual occurrences of expressions in concrete contexts can be used to compare 
the variation in meaning between different language-specific expressions. So, instead of assuming that we know what the English expression walk means, I propose to sample its meaning by considering various contextualized occurrences of walk-like situations. To compare expressions across languages, ideally the same sample of contexts should be used for all languages investigated. The parallel collection of such occurrences across languages can take various forms. It is possible to use extra-linguistic stimuli, like pictures (e.g. Levinson \& Meira 2003) or video sequences (e.g. Majid et al. 2007), and investigate the linguistic expressions used to describe them. The contexts can also be defined purely linguistically, using descriptions of situations (e.g. Dahl 1985) or examples from parallel texts (e.g. Wälchli 2005).

In the practice of grammatical typology it is often impossible to collect sufficient parallel expressions because of the limited amount of material available and because of the difficulty of finding native speakers for all the languages to be investigated. So, instead of concrete occurrences of language-specific expressions in context, normally somewhat larger domains of contexts are used in which an expression can occur (e.g. Haspelmath 1997). These domains are (more or less) explicitly defined as "chunks" of meaning, large enough to be identifiable from reference grammars, and small enough to capture the main distinctions of the cross-linguistic variation. ${ }^{1}$ Both parallel expressions in context as well as the somewhat more abstract domains of meaning as used conventionally in linguistic typology are called ANALYTICAL PRIMITIVES in Cysouw (2007). ${ }^{2}$

One of the consequences of comparing languages on the basis of an (empirical) selection of analytical primitives is that such a selection strongly reduces the range of possible meanings that can be identified across languages. Instead of the real-world continuous variation of possible meanings, a (finite) sample of analytical primitives only allows for a restricted, point-wise, granular view on this variation. In this approach, the meaning of a language-specific expression reduces to a subset of the sampled primitives. This subset consists of those sampled contexts in which the language-specific expression occurs. From the perspective of individual languages, the semantic analysis offered on the basis of such a selection of primitives might be somewhat coarse-grained and perhaps to some extent even misleading. The most important gain of this approach, however, is that it offers a concrete operationalization of the cross-linguistic study of meaning. From this perspective, the comparison of the meanings of two expressions from two different languages consists in the comparison of the selected subsets of analytical primitives. Any deficits in the comparison arising from a biased selection of analytical primitives can easily be repaired by changing or extending the sample of primitives.

To be able to make cross-linguistic comparisons between language-specific expressions from different languages, first the internal structure among the primitives must be considered. This paper deals with the empirical establishment of such structure among analytical primitives in the form of semantic maps (Section 2). The actual comparison of language-specific expressions (i.e. questions like "how similar is English walk to Spanish andar, and in which aspects to they differ?") will not be further pursued here. ${ }^{3}$ In a very general sense, the structure among analytical primitives amounts to establishing a metric on analytic primitives, i.e. a specification of the

\footnotetext{
${ }^{1}$ It might be worthwhile to consider more precise definitions of such chunks of meaning as used in typology, for example using Natural Semantic Metalanguage (Wierzbicka 1996).

${ }^{2}$ The terms "comparative concept" as used by Haspelmath (2010) and "etic grid" as used by Levinson \& Meira (2003: 487) are highly similar, if not identical, concepts to what I call "analytical primitive".

${ }^{3}$ For some first attempts at comparing the meaning of language-specific expressions, see Cysouw (2007) and Wälchli \& Cysouw (2010).
} 
distances (or "dissimilarities") between them, as will be discussed in Section 3. One way to empirically arrive at these dissimilarities between primitives is to use cross-linguistic diversity in the encoding of the primitives, as discussed in Section 4. Only language-specific analysis is necessary to establish dissimilarities between primitives-no cross-linguistic judgements are necessary. This important insight led to the establishment of semantic maps in the first place but will be generalized here in Section 5. In Section 6, I will argue that both form and behavior can be analyzed as language-specific encoding. An example of this conceptualization of the cross-linguistic study of meaning is presented in Section 7, in which data from Haspelmath (1993) on the inchoative/causative alternation is reanalyzed.

\section{Semantic Maps}

Analytical primitives are not just points in an unstructured cloud of semantic space. Some primitives are more similar to each other than to others. Such structure among analytical primitives is suitably analyzed by using semantic maps (cf. Haspelmath 2003). Semantic maps are a special kind of analysis and display of the internal structure of a sample of analytical primitives. My use of the terms SEMANTIC SPACE and SEMANTIC MAP is most closely related to Haspelmath's terminology, in which "a semantic map is a geometrical representation of functions in 'conceptual/semantic space'" (Haspelmath 2003:213). This is different from the terminology used by Croft (although there is no difference in content), who uses the term "conceptual space" for the geometrical representation, and "semantic map" for the languagespecific instantiation (cf. Croft 2001:92ff; Croft 2003:133-139; Croft \& Poole 2008:3). The different terminologies are summarized in Table 1.

Differently from the received view of such semantic maps, I propose here to strictly separate the notion of a semantic map into two different aspects, namely the STRUCTURE among the primitives and the DISPLAY of this structure. The structure itself will be formulated as a metric on the primitives; the display of the structure is the semantic map proper. Given a particular set of data, there will both be different ways to establish the structure among the primitives, and there will be different ways to display any structure attested. Because of the multitude of possibilities, it is particularly important to separate effects stemming from the decision on how to measure the structure from effects resulting from the specific method of visualizing the structure. In this paper, I will only discuss approaches to the establishment of the structure among primitives. The discussion of the various possible visualizations will be left for another occasion. 


\begin{tabular}{lccl}
\hline \multicolumn{1}{c}{ Concept } & \multicolumn{3}{c}{ Terminology } \\
\cline { 2 - 4 } & This paper & Haspelmath & Croft \\
\hline Collection of all possible & conceptual/ & conceptual/ & - \\
analytical primitives & semantic space & semantic space & \\
\hline Structure within the set & cross-linguistic & semantic map & conceptual space \\
of analytical primitives & metric on meaning & & \\
\hline Graphical representation & semantic map & semantic map & conceptual space \\
of attested structure & & & \\
\hline Language-specific encoding & language-specific & boundaries in & semantic map \\
of analytical primitives & metric on meaning & semantic map & \\
\hline Graphical representation of & language map & boundaries in & semantic map \\
language-specific encoding & & semantic map & \\
\hline
\end{tabular}

\section{Metrics and Distance Matrices}

A METRIC is the mathematical explication of a notion of distance (or dissimilarity, i.e. the opposite of similarity). In our daily world, the most natural notion of distance is the Euclidean distance, i.e. the distance "as the crow flies". However, when moving from point A to B it is often not possible to take the direct route (if you are not a crow), so another natural metric is the ground travel distance. This notion of distance can widely deviate from the straight-line Euclidean distance, namely when there is no (approximately) direct route to get from A to B while staying on the ground. Still another way to measure distance in daily life is to take the time it takes to get from A to B. Again, this notion of distance might give a rather different perspective on our surroundings depending on transportation possibilities. These different ways of measuring distance illustrate that any notion of distance is a question of perspective and is not in any sense pre-established by the nature of the objects investigated. This holds also for metrics on meaning: what counts as similar in meaning depends on which perspective one wants to take. ${ }^{4}$

The result of applying a metric on some data is a table of pairwise distances for all pairs of objects investigated: a DISTANCE MATRIX. So, given some data and a decision on how to interpret the data (the metric), distances between pairs of objects can be computed. Normally, such pairwise distances are expressed as a (fractional) number between zero and one. At the one extreme " 0 " indicates "no distance", i.e. the two objects are the same, and at the other extreme " 1 " indicates "maximal distance", i.e. the objects are completely different. It is not necessary to

\footnotetext{
${ }^{4}$ It is an open question whether different approaches to measuring meaning converge. If something like "the" meaning exists, then this should be the case. Given the framework for investigating meaning as sketched in this paper, this question becomes an empirical problem.
} 
normalize distances to this zero-one interval, but it makes it easier to combine distance matrices. Also, decimally written values between zero and one can intuitively be taken to represent percentages. For example, a distance of 0.54733 can be interpreted as "almost $55 \%$ of the maximal distance". And, finally, the distances between zero and one are easily switched to similarities, because when two objects have a distance of $d$, then they have a similarity of $1-d$.

Distance matrices can become bewilderingly large and difficult to interpret for a human being. For example, with only 10 analytical primitives there are already $10 \times 9 \div 2=45$ distances between pairs of primitives. Just looking at such a long list of numbers will normally not result in very revealing insights because it is difficult to identify meaningful distinctions amid the wealth of available information. There are many ways to help a human being make sense of what would otherwise be categorized as information overload, but this is an extensive topic which I will not discuss in detail here. Suffice it to say that visualization is a highly powerful technique, though it can also be deceptive because human eyes (and brains) tend to see patterns even when there are none. For this reason it is advisable never to rely on just one visualization and to always determine afterwards whether any patterns perceived are really statistically significant. Finally, it is important to recognize that every visualization is always an abstraction of the underlying data, or, put more bluntly, many details are necessarily ignored, or intentionally misrepresented, in the process of making a visually pleasing graphic display. The network-like graph used for traditional semantic maps (cf. Haspelmath 2003) is an example of such a pleasing graphic display for which various fundamental abstractions of the available data are made (cf. Cysouw 2007 for a detailed criticism).

\section{Using Linguistic Diversity}

The basic intuition behind the semantic map approach to meaning is that cross-linguistic variation in the expression of meaning can be used as a proxy to the investigation of meaning itself. Concretely, recurrent similarity in form reflects similarity in meaning, or, as Haiman (1985:19) puts it: "recurrent identity of form between different grammatical categories will always reflect some perceived similarity in communicative function." Thus, the assumption is that when the expression of two meanings is similar in language after language, then the two meanings themselves are similar. Individual languages might (and will) deviate from any general pattern, but when combining many languages, overall the cross-linguistic regularities will overshadow such aberrant cases. ${ }^{5}$

Formulated within the framework set up in the previous sections, this basic intuition can be formalized as follows. To start off, a sample of analytical primitives has to be established, and expressions of these primitives must be collected for a sample of the world's languages. Then, for each language individually, the similarity between these expressions can be established within the structure of the language (i.e. only language-specific constructions and languageinternal form-similarities are investigated). Technically formulated, this means that a languagespecific metric on the expressions will be set up - a different one for each language (see Section

\footnotetext{
${ }^{5}$ This approach assumes that every meaning is expressible in all human languages. The expression of a meaning might be easier in some languages and take more effort in others, but it is possible everywhere. However, there are various obvious complications with this assumption; see for example Levinson (2003) for a challenge to this assumption regarding the expression of spatial concepts. Further, I will ignore the complications arising from the fact that most languages will have many different ways to express a particular meaning. This is not problematic for the goal of computing meaning similarities, but the mathematical details will become a bit more involved.
} 
7.2 for a concrete example of how this might work). Then, the cross-linguistic metric on the analytical primitives ("semantic map") is the average of the language-specific metrics on the expressions collected. This simple statement represents a big step forward for any empirical investigation of meaning (cf. Haspelmath 2003:230-233). Instead of requiring elusive judgments about the similarities between meanings, all that is needed now are very concrete judgments about the similarity between language-specific expressions within one and the same language. So, to establish a cross-linguistically viable metric on meaning, it is not necessary to perform cross-linguistic comparisons of expressions from different languages. Purely on the basis of many language-specific analyses, it is possible to arrive at general results.

\section{Constructions and Strategies}

To establish a metric on expressions, a notion of (dis)similarity between expressions is needed. There are basically two different kinds of (dis)similarity. The first possibility is to compare the amount of shared morphophonological material between expressions. Such similarity is purely language-specific and cannot be used to directly compare expressions across languages (except of course in historical-comparative reconstruction). In contrast, more abstract characteristics are necessary to establish the cross-linguistic similarity between expressions. Examples of more abstract characteristics are the order of elements, the length of expressions, or the degree of fusion between elements (e.g. isolation, concatenation, or non-linear morphology). This is an important differentiation, as made implicitly in the semantic map literature. The first similarity leads to a LANGUAGE-SPECIFIC EXPRESSION METRIC ("constructions") and the second to a CROSSLINGUISTIC EXPRESSION METRIC ("strategies"). Most of the comparisons in the field of linguistic typology are based on comparing cross-linguistic strategies (cf. Croft 2003:31ff.). However, semantic maps are purely based on language-specific constructions.

Given a language-specific metric, a LANGUAGE-SPECIFIC CONSTRUCTION (in the sense of Croft 2001; Goldberg 2006) is a set of language-specific expressions that are highly similar from the perspective of the metric. What exactly "highly similar" means is of course less obvious, but any disputable similarity-boundary will likely be reflected by an equally vague notion of what defines the construction involved. Though different operationalizations of similarity can be used (and see Section 7 for a few possibilities), I am strongly in favor of a gradient notion of language-specific constructions (i.e. individual expressions in a language are more or less similar on a continuous scale). I think it is misguided to look for any strict definition of constructions that discretely classifies all expressions of a language into separate constructions.

Being the counterpart to constructions, a TYPOLOGICAL STRATEGY is a set of expressions that are highly similar from the perspective of a cross-linguistic metric (the term "strategy", now commonly found in the typological literature, was probably first used in this sense by Keenan \& Comrie 1977:64). Just as constructions are abstractions of language-specific metrics, strategies are abstractions of cross-linguistic metrics. For example, consider the causative/inchoative alternation, to be discussed extensively in Section 7. The English inchoative expression the vessel is destroyed has a causative counterpart the torpedo destroyed the vessel. Now, the language-specific construction to derive the anticausative from the causative in English for the verb destroy is to use an expression with the verb to be. From a cross-linguistic perspective, this alternation is an example of an "anticausative" typological strategy, using the terminology of Haspelmath (1993:91), because the inchoative is transparently derived from the causative.

The main claim of the semantic map approach is that a metric on meaning ("semantic 
map") can be established purely on the basis of many language-specific expression metrics ("constructions"), averaged over a diverse sample of languages. Cross-linguistic metrics ("strategies") are not necessary for this goal. ${ }^{6}$

\section{Coding and Behavior}

There are many different ways to establish a language-specific expression metric. In the next section, concrete examples of three different metrics on the same data will be discussed in detail. One somewhat atypical aspect of the following examples is that the metrics are based on pairs of expressions, not on single expressions as in traditional semantic maps (Haspelmath 2003). This approach - considering the relation between two expressions-is reminiscent of Keenan's (1976:306-307) "transformational behavior". Following Keenan, the terms "coding" and "behavior" have become widespread for the analysis of grammatical relations. Generalizing this distinction, I will use the term "coding properties" for properties of individual expressions, while "behavioral properties" are properties of the relation between expressions.

The properties may be pragmatic, semantic, or syntactic. And of the syntactic ones, some concern properties internal to a single sentence [i.e. "coding", MC] and others concern the relation between a b-sentence and some modification of it [i.e. "behavior", MC]. (Keenan 1976:312)

Under this definition, the opposition coding vs. behavior is independent from the opposition construction vs. strategy, as discussed in the previous section. There are thus four logically possible combinations that represent different approaches to characterizing and comparing expressions.

First, a coding strategy is a cross-linguistic classification of the structure of a particular expression. This is the most prototypical kind of approach in linguistic typology. The classic example is the typology of relative clause structures distinguishing types like "relative pronoun strategy" or the "internally headed relative clauses" (Lehmann 1984; Comrie \& Kuteva 2005). Second, a behavioral strategy is a cross-linguistic classification of the relation between various expressions (typically two, but possibly more). A classic example is the relation between a regular matrix sentence like John swept the floor and the corresponding action nominal construction John's sweeping of the floor (cf. Keenan 1976:321). For this behavior, a crosslinguistic classification of possible strategies used by human languages has been developed by Koptjevskaya-Tamm (1993, 2005).

Third, constructional coding is a characterization of the language-specific form of a expression. This is the typical information that is used in traditional semantic maps. The more similar two expressions are in terms of their constructional coding, the closer their meaning (when averaged over a large number of languages). Finally, constructional behavior is the fourth possibility. This method of characterizing expressions is not very widely acknowledged in

\footnotetext{
${ }^{6}$ One auspicious prospect is that an association between a cross-linguistic metric ("strategy") and a language-specific metric ("construction") represents a generalization of what is known in linguistics as a "hierarchy" or a "scale". Establishing such a correlation is not trivial because language-specific metrics cannot be compared directly across languages (see the example at the end of Section 7.2 for a first glimpse of this prospect and see Cysouw 2008 for a more elaborate discussion).
} 
the typological literature, but it will be the approach that I will use in the case study in the next section. The basic idea is to compare the combined language-specific forms of all alternative expressions that are relevant for the behavior.

\section{Case Study}

\subsection{Causative/inchoative alternations}

As an example of the approach presented here, I will reanalyze the data from Haspelmath (1993) on the causative/inchoative alternation. In his paper Haspelmath addresses the question as to how languages mark the predicate in the alternation between an inchoative expression like the water boiled and a causative expression like the man boiled the water. In the case of the English predicate boil there is no difference in the marking, but for other alternations, like die/kill or be destroyed/destroy, the difference between the inchoative and the causative version is reflected in the lexical or morphological form of the predicate. The approach of Haspelmath's study is to investigate cross-linguistic strategies of expressing the relation between inchoative and causative meanings, but that aspect of his study will not be the main focus of this paper (some preliminary hints on the relation between strategies and meaning will be given at the end of Section 7.2). Instead, I will investigate the relations between the meanings of the predicates by investigating the language-specific marking that is used to express the inchoative/causative alternation.

Haspelmath investigated the inchoative/causative alternation for 31 analytical primitives ("lexical meanings") in 21 languages. The 31 meanings investigated are repeated here in Table 2 (adapted from Table 2 in Haspelmath 1993:97). ${ }^{7}$ The translations of these meanings in all 21 languages are added as an appendix to Haspelmath's paper, allowing for the current reanalysis of the data. ${ }^{8}$

\footnotetext{
${ }^{7}$ The primitives used in this paper represent a somewhat special kind of lexical meaning because they are neutral with respect to the causative/inchoative alternation. For example, the English pair kill/die is considered to be a single primitive here, notwithstanding the lexical suppletion. It is important to realize that not all languages have suppletion for the same primitives, so cross-linguistically the pair kill/die has to be treated as equivalent to a nonsuppletive pair like destroy/be destroyed.

${ }^{8}$ To simplify the calculations, I have maximally included one expression for each meaning in each language. In some cases, Haspelmath lists more than one possible expression, and in those cases I have semi-randomly chosen one of the options. If possible, I have discarded idiosyncratic alternations showing inchoative/causative morphology that was not found in any other sampled expressions of the same language. Only when all alternatives used constructions which are also found elsewhere did I randomly select one of them. This was only necessary in a handful of cases.
} 


\begin{tabular}{|c|c|c|c|c|c|}
\hline No. & Inchoative & Causative & No. & Inchoative & Causative \\
\hline 1 & wake up & wake up & 17 & connect & connect \\
\hline 2 & break & break & 18 & boil & boil \\
\hline 3 & burn & burn & 19 & rock & rock \\
\hline 4 & die & kill & 20 & go out & put out \\
\hline 5 & open & open & 21 & rise & raise \\
\hline 6 & close & close & 22 & finish & finish \\
\hline 7 & begin & begin & 23 & turn & turn \\
\hline 8 & learn & teach & 24 & roll & roll \\
\hline 9 & gather & gather & 25 & freeze & freeze \\
\hline 10 & spread & spread & 26 & dissolve & dissolve \\
\hline 11 & $\operatorname{sink}$ & $\operatorname{sink}$ & 27 & fill & fill \\
\hline 12 & change & change & 28 & improve & improve \\
\hline 13 & melt & melt & 29 & dry & dry \\
\hline 14 & be destroyed & destroy & 30 & split & split \\
\hline 15 & get lost & lose & 31 & stop & stop \\
\hline 16 & develop & develop & & & \\
\hline
\end{tabular}

I will use the language-specific marking of the inchoative/causative alternation of the meanings listed in Table 2 as a proxy to the measurement of the similarity between the meanings. For example, the English expression of meaning 1, wake up/wake up, does not use any marking to differentiate inchoative from causative. This means that meaning 1 is somewhat alike to meaning 2, in English expressed as break/break, which likewise does not differentiate inchoative from causative. A similar situation is found in French. The French expressions of meanings 1 and 2 also use the same construction (viz. a reflexive pronoun with the inchoative: se réveiller/réveiller and se briser/briser, respectively). This is again an indication that these two meanings are somewhat alike. In German, though, meanings 1 and 2 do not use the same process (viz. an ablaut-like alternation in aufwachen/aufwecken vs. no differentiation in zerbrechen/zerbrechen, respectively), which is an indication that the meanings 1 and 2 are also somewhat different.

The marking of the inchoative/causative alternation on the predicate is just one of very many possible approaches to investigating similarity between meanings, or, to paraphrase a claim made in Section 3, any notion of similarity is a question of perspective and is not in any sense preestablished by the nature of the expressions investigated. The rather abstract nature of the notion of similarity as used here (i.e. the formation of the inchoative/causative alternation) is appealing because it allows for the comparison of otherwise difficult-to-compare meanings, like "wake up" 
and "break". 9 In the following section, I will discuss three different ways to operationalize this language-specific notion of similarity between expressions.

\subsection{Metric A: Language-specific constructions}

The first example of a language-specific similarity between expressions will be based on establishing language-specific constructions. I will here define a construction as a regular morphosyntactic relation between an inchoative and a causative verb form. Such relations are purely language-specific (see the appendix for a complete survey of all constructions distinguished for this paper). For example, in English, the 31 meanings shown in Table 2 can be classified as belonging to seven language-specific constructions. There is one large class consisting of verbs that do not show any difference in morphology between inchoative and causative usage (viz. wake up, break, burn, open, etc.). The remaining six classes each consist only of one meaning, using different inchoative/causative alternations in each case (viz. die/kill, learn/teach, be destroyed/destroy, get lost/lose, go out/put out, and rise/raise). As an example, just the first three meanings are shown in Table 3, all three being marked as belonging to the same class (called "E-1", where the "E" indicates that this is a language-specific class for English only).

For other languages, these classifications will look different. For example, in French there are five different classes. First, there is one large class in which the inchoative form is marked with a reflexive pronoun (e.g. 1: se réveiller/réveiller and 2: se briser/briser). Second, there is another large class in which there is no difference between inchoative and causative verb forms (e.g. 3: brûler/brûler). Then, there is a small class where the causative is formed by adding the verb faire (among the current 31 meanings this is found only for 13: fondre/faire fondre and 18: bouillir/faire bouillir). Finally, there are two French expressions that do not have any parallel among the current 31 meanings, so they make up their own class (viz. 4: mourir/tuer and 14: être détruit/détruir).

\begin{tabular}{ccccccc}
\hline & English & \multicolumn{3}{c}{ French } & \multicolumn{3}{c}{ German } \\
No. & Form & Class & Form & Class & Form & Class \\
\hline 1 & wake up/wake up & E-1 & se réveiller/réveiller & F-1 & aufwachen/aufwecken & G-1 \\
2 & break/break & E-1 & se briser/briser & F-1 & zerbrechen/zerbrechen & G-2 \\
3 & burn/burn & E-1 & brûler/brûler & F-2 & verbrennen/verbrennen & G-2 \\
\hline
\end{tabular}

Table 3: Excerpt of language-specific classes for inchoative/causative alternations

Once established for all languages in the sample, these language-specific classes ("constructions") can now be used to calculate the (dis)similarity between the primitives ("lexical meanings"). Basically, every pair of meanings is considered separately for all 21 languages, and the number of languages is counted for which the two meanings belong to different constructions. The higher this number, the more languages put the meanings in different constructions, indicating that the meanings are different. For example, considering meanings 1

\footnotetext{
${ }^{9}$ Most theories of meaning will not have much to say about the relation between "wake up" and "break" other than coincidental points such as the observation that in English the metaphor break of day is used for the morning, which is also the prototypical time to wake up.
} 
and 2 in the excerpt of the data shown in Table 3, these two meanings belong to the same class in English and in French, but to different constructions in just one language, namely German. So, the distance between meaning 1 and 2 is " 1 ". Likewise, the distance between 1 and 3 is " 2 " because two of these languages treat them differently, and between 2 and 3 the distance is " 1 " because only French treats them differently. The establishment of the language-specific constructions and the counting of differences together are a metric on meanings, and the result is a list of distances between all pairs of meanings.

A different way of performing exactly the same calculation is obtained by a reformulation of the language-specific constructions into language-specific distance matrices. This reformulation might seem somewhat cumbersome at first, but it will allow for a much wider array of possible analyses - a few of which will be discussed in the next sections. The basic idea is to consider a language-specific construction to be a very simple notion of dissimilarity. As defined earlier, a construction can be considered to be a language-specific metric on expressions (cf. Table 1 and the discussion in Section 5). Such a metric only allows for the options "identical" (i.e. a dissimilarity/distance of " 0 ") or "different" (i.e. a dissimilarity/distance of " 1 "). From the perspective of English, the meanings 1,2, and 3 are all identical (i.e. they belong to the same construction), which translates to a distance of zero between all pairs of these meanings. Of course, also the distance between each meaning and itself is zero (they necessarily belong to the same construction), so the result of reformulating the first three English meanings into a language-specific distance matrix is a matrix with all zeros (cf. the leftmost matrix in Figure 1for convenience of presentation all matrices are shown completely, although distance matrices redundantly duplicate each entry in the upper and lower triangle). The same procedure can also be used for French and German, which will result in some distances of "1" because not all three meanings belong to the same class in these languages. Given these language-specific distance matrices, the cross-linguistic distance matrix on the meanings can now easily be computed by summing up these three matrices (cf. the rightmost matrix in Figure 1). ${ }^{10}$
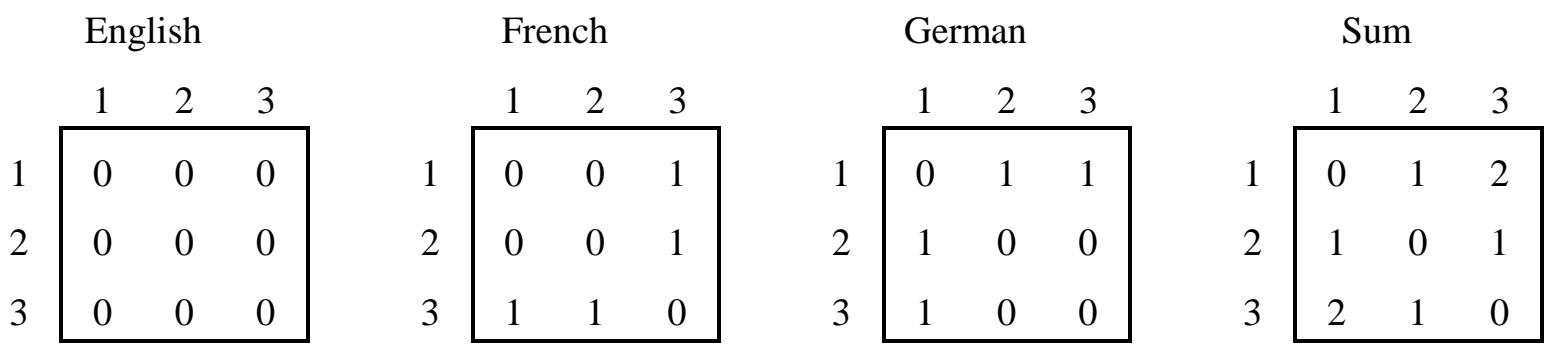

Figure 1: Language-specific constructions as distance matrices. Adding them together results in a cross-linguistic distance matrix on the meanings

Doing these calculations for all 31 meanings in all 21 languages results in a $31 \times 31$ crosslinguistic distance matrix giving the dissimilarity for all pairs of meanings — an excerpt of which is shown in Table 4. The minimal value in this table is zero (i.e. the meanings belong to the same construction in all 21 languages), and the maximum is 21 (i.e. the meanings belong to different

\footnotetext{
${ }^{10}$ This reformulation opens up the possibility of comparing the structure of lexicalization between languages. This can be done by correlating the language-specific distance matrices from Figure 1. In effect, each distance matrix represents the language-specific perspective on the relation between the meanings. The similarity between two such matrices can be interpreted as a measure of how similarly languages deal with the coding of meanings. The details and implications of this approach to language comparison have to be left for another paper though.
} 
constructions in all 21 languages). These values can be normalized to the [0,1] interval by dividing them by 21 (shown in parentheses in the table). Just to give some perspective on these numbers, it appears that the pairs "close"-“open", "open"-"break", and "close"-"break" are relatively similar (they belong to the same construction in about half of the languages investigated). In contrast, "die/kill" is highly dissimilar from all others, as might have been expected, because the inchoative/causative alternation for this meaning is suppletive in most languages and thus different from all other alternations in the same language.

\begin{tabular}{ccccccc}
\hline & wake up & break & burn & die/kill & open & close \\
\hline wake up & 0 & $17(.81)$ & $16(.76)$ & $20(.95)$ & $17(.81)$ & $16(.76)$ \\
break & $17(.81)$ & 0 & $13(.62)$ & $19(.90)$ & $10(.48)$ & $12(.57)$ \\
burn & $16(.76)$ & $13(.62)$ & 0 & $20(.95)$ & $16(.76)$ & $17(.81)$ \\
die/kill & $20(.95)$ & $19(.90)$ & $20(.95)$ & 0 & $21(1.0)$ & $21(1.0)$ \\
open & $17(.81)$ & $10(.48)$ & $16(.76)$ & $21(1.0)$ & 0 & $10(.48)$ \\
close & $16(.76)$ & $12(.57)$ & $17(.81)$ & $21(1.0)$ & $10(.48)$ & 0 \\
\hline
\end{tabular}

Table 4: Excerpt of the cross-linguistic dissimilarity matrix on meaning as established by summing up over all 21 languagespecific classifications

A complete analysis of the full $31 \times 31$ distance matrix will not be pursued here, but one quick example will be given to indicate possible routes of analysis (see Cysouw 2008 for a more elaborate discussion). When multidimensional scaling is applied to the cross-linguistic distance matrix, then the first dimension (i.e. the dimension that explains most of the variation) appears to be related to the "scale of likelihood of spontaneous occurrence" (Haspelmath 1993:105). ${ }^{11}$ On one side of this scale predicates are found that prototypically do not need an agentive instigator, like "boil", "freeze", and "burn" (and in the multidimensional scaling "die/kill" is also found to belong to this side). The other side of the scale holds such events that normally have a human agent, like "gather", "connect", or "change". This scale was originally proposed by Haspelmath to explain the preference of certain meanings for particular behavioral strategies. Specifically, he argued that those meanings that are typically in need of a human instigator cross-linguistically have a preference for an anticausative coding strategy (i.e. the inchoative is derived from the causative), while the meanings on the other side of the scale have a preference for a causative strategy (i.e. the causative is derived from the inchoative).

Now, instead of deriving the scale of likelihood of spontaneous occurrence from behavioral strategies, as Haspelmath did, in this paper the scale is purely based on the analysis of languagespecific constructions. The semantic scale of likelihood of spontaneous occurrence (here defined as the first dimension of the MDS of the metric on meaning) can then be correlated empirically with the proportion of languages that use an anticausative strategy (see Figure 2). ${ }^{12}$ The

\footnotetext{
${ }^{11}$ For this calculation, classic multidimensional scaling was used through the implementation "cmdscale" in the statistical environment R (R Development Core Team 2007). All other calculations and graphs in this paper were also produced by using $\mathrm{R}$.

${ }^{12}$ Haspelmath, following up on earlier work by Nedjalkov, uses the fraction of anticausative by causative (A/C) strategies as an index for the cross linguistic preference for either of these strategies. The usage of this particular fraction is unfortunate because the resulting values are very unevenly distributed (they range between zero and infinite). I have used $\mathrm{A} /(\mathrm{A}+\mathrm{C})$ here instead. Another possibility would be to use $\log (\mathrm{A} / \mathrm{C})$.
} 
correlation is almost perfect $\left(r=.83, p<10^{-8}\right)$. This example indicates that a linguistic scale can be conceived of as a (significant) correlation between meaning-similarity and form-similarity.

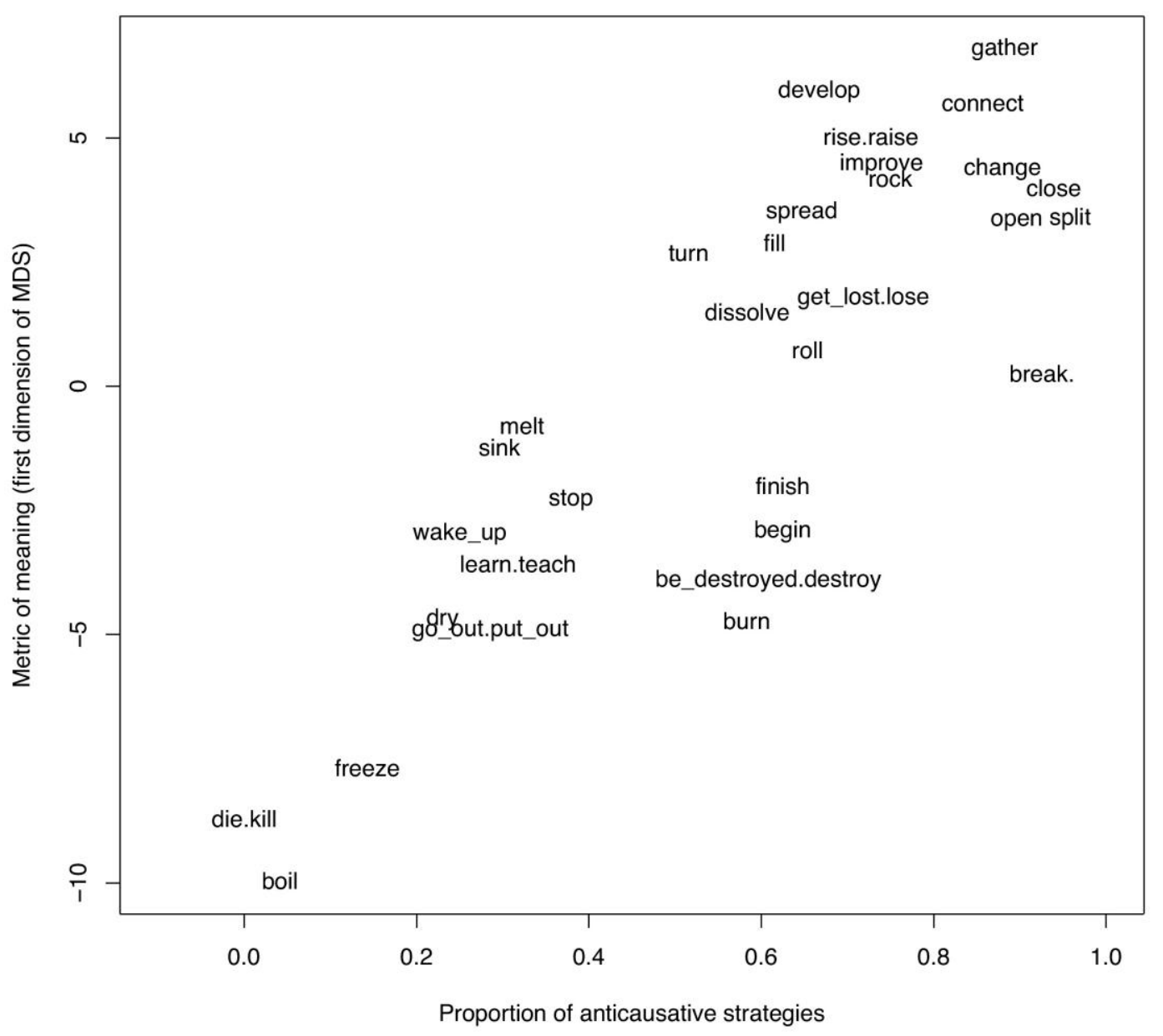

Figure 2: Correlation between preference for anticausative coding strategy and the first dimension of the MDS of the metric of meaning.

\subsection{Metric B: Algorithmically approximating constructions}

The reformulation of constructions as language-specific metrics on expressions, as discussed in relation to Figure 1 above, allows for a wide variety of other approaches to establishing a semantic map. The basic idea of this reformulation is that for each language a language-specific distance matrix is calculated describing how similar the expressions of the meanings are from the perspective of each language individually. The cross-linguistic distances then are the result of simply summing up over all these language-specific distances. Using constructions, as done in the previous section, the language-specific matrices will only consist of " 0 " (indicating "same construction") and " 1 " (indicating "different constructions"). However, all values in between " 0 " and " 1 " can also be used to indicate that two constructions are neither completely different nor completely similar. For example, one might argue that the German alternations 
aufwachen/aufwecken and versinken/versenken are different constructions, but also somewhat alike. They both involve a kind of ablaut, though the details are different. Neither considering them to be completely different nor completely identical will do justice to the empirical situation. To deal with such a situation, a gradient language-specific distance can be used. For example, one could set the language-specific distance between the two alternations above as 0.75 (see Table 5). The specification of gradient dissimilarities can be performed on the basis of a detailed analysis of each language individually. However, it is also possible to use a general method for measuring language-internal similarity. One such approach will be discussed in this section, and a simpler but also less satisfying method will be discussed in the next section.

\begin{tabular}{ccccccccccc}
\hline & & \multicolumn{3}{c}{ Yes/No distance } & \multicolumn{3}{c}{ Gradient distance } \\
No. & German expressions & 1 & 2 & 3 & 11 & 1 & 2 & 3 & 11 \\
\hline 1 & aufwachen/aufwecken & 0 & 1 & 1 & 1 & 0 & 1 & 1 & .75 \\
2 & zerbrechen/zerbrechen & 1 & 0 & 0 & 1 & 1 & 0 & 0 & 1 \\
3 & verbrennen/verbrennen & 1 & 0 & 0 & 1 & 1 & 0 & 0 & 1 \\
11 & versinken/versenken & 1 & 1 & 1 & 0 & .75 & 1 & 1 & 0 \\
\hline \multicolumn{4}{c}{ Table 5: Different language-specific distances of some German inchoative/causative alternations }
\end{tabular}

One method of comparing inchoative/causative alternations within the structure of a single language is to analyze each alternation as a collection of changes of letters needed to get from the inchoative to the causative string of letters. Changes are either a deletion of an existing letter or an insertion of a new letter. To match linguistic intuitions about what makes a similar change, the method distinguishes between making a change at the start of a word, at the end of a word, or in the middle of a word. For every inchoative/causative pair, this leads to a list of changes on how to get from the inchoative to the causative form. So, for example, to get from rise to raise only one change is needed, namely an $\langle a>$ has to be inserted in the middle of the word. To compare two alternations, the number of shared letter changes is counted and then normalized by the maximum number of changes attested. The distance between two alternations will then be the complement of this value (i.e. 1-shared/maximum).

For example, to get from the German inchoative aufwachen to causative aufwecken the following four changes are needed:

1) deletion of $<\mathrm{a}>$ inside the word ("aufwchen")

2) deletion of $<\mathrm{h}>$ inside the word ("aufwcen")

3) insertion of $<\mathrm{e}>$ inside the word ("aufwecen")

4) insertion of $<\mathrm{k}>$ inside the word ("aufwecken")

To get from German inchoative versinken to causative versenken the following two changes are needed:

1) deletion of $<i>$ inside the word ("versnken")

2) insertion of $<\mathrm{e}>$ inside the word ("versenken")

These two sets of changes have one change in common ("insertion of $<\mathrm{e}>$ inside the word"), and 
the maximum number of changes needed is "4" (for the aufwachen/aufwecken alternation), so the distance between the two alternations is $1-1 / 4=.75$ (cf. Table 5). This algorithm could be improved in various ways. ${ }^{13}$ However, the main point is that it is relatively easy to get a rough estimate of the language-internal dissimilarity between two inchoative/causative alternations. ${ }^{14}$

To get from language-specific dissimilarities to a cross-linguistic distance matrix, all individual matrices are added together. An excerpt of the resulting matrix is shown in Table 6, which can be compared with the same selection shown in Table 4. Although the two tables are not completely identical, the values are astonishingly close. The complete correlation between the results of this algorithmic notion of dissimilarity and the dissimilarity based on the manually established language-specific constructions is shown in Figure $3(r=.91)$. Shown on the $\mathrm{X}$-axis in this figure are the dissimilarities ("distances") from the metric discussion in the previous Section 7.2. On the y-axis, the distances from the algorithmic approach as discussed in this section are shown. The close match between these two methods suggests that automatic approaches can be very useful in the establishment of cross-linguistic metrics on meaning. In general, it appears that the errors introduced by the linguistically naive algorithm are easily corrected by summing up over many languages.

\begin{tabular}{ccccccc}
\hline & wake up & break & burn & die/kill & open & close \\
\hline wake up & 0 & $14.1(.67)$ & $14.5(.69)$ & $18.5(.88)$ & $13.8(.66)$ & $13.5(.64)$ \\
break & $14.1(.67)$ & 0 & $12.7(.61)$ & $17.5(.83)$ & $10.2(.49)$ & $10.8(.51)$ \\
burn & $14.5(.69)$ & $12.7(.61)$ & 0 & $17(.81)$ & $14.5(.69)$ & $15.4(.73)$ \\
die/kill & $18.5(.88)$ & $17.5(.83)$ & $17(.81)$ & 0 & $18.7(.89)$ & $18.6(.89)$ \\
open & $13.8(.66)$ & $10.2(.49)$ & $14.5(.69)$ & $18.7(.89)$ & 0 & $10.3(.49)$ \\
close & $13.5(.64)$ & $10.8(.51)$ & $15.4(.73)$ & $18.6(.89)$ & $10.3(.49)$ & 0 \\
\hline \multicolumn{7}{c}{ Table 6: Excerpt of the cross-linguistic distance matrix as established by the algorithmic approach }
\end{tabular}

\footnotetext{
${ }^{13}$ There are various questionable decisions being made in this algorithm. First, it operates on letters, where ideally it would work on sounds. Second, there is no reason to restrict the algorithm to only insertions and deletions-also exchanges could be used, or other operations. Further, every insertion and deletion is equally weighted, though some might be more significant than others. And instead of dividing by the maximum number of changes one could also use another normalization like dividing by the average number of changes.

${ }^{14}$ I thank Hagen Jung for assistance with the implementation of this algorithm.
} 


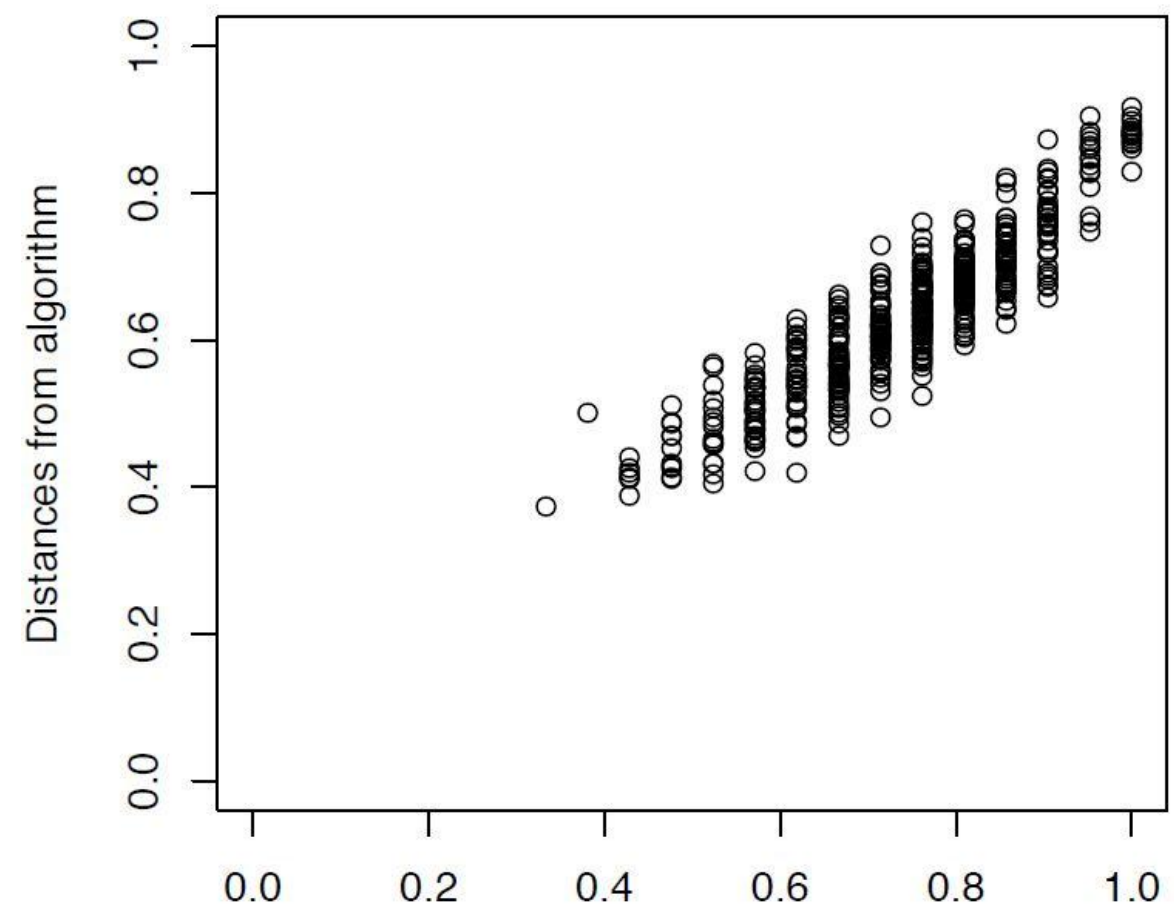

Distances from language-particular classes

Figure 3: Correlation between cross-linguistic distances as established by language-specific classes and by the algorithmic approach

\subsection{Metric C: Simplistic string-based similarity}

The good results of the algorithmic approach to establishing language-specific similarities prompted me to try out an even simpler, even more linguistically naive algorithmic approach. It is based on the LONGEST COMMON SUBSTRING measure of similarity between two strings of letters. This similarity consists of the length of the longest consecutive stretch of letters shared between two expressions. So, for example, house and mouse share 4 letters in a row. To use this measure of similarity for inchoative/causative alternations, I pasted the inchoative and the causative forms together into one string without spaces (e.g. French seréveillerréveiller or sebriserbriser) and established the longest common substring (in the French example this would be " 2 " for the string "se"). This approach of course finds all kinds of small random similarities (e.g. wakeupwakeup and breakbreak also have a longest common substring of " 2 " for the string " $a k$ "), and in general it only works well with concatenative morphology or morphologically independent markers (like the reflexive $s e$ in the French example above).

Figure 4 shows the relation between the distances from this very simplistic approach (shown on the y-axis) to the distances from the linguistically sophisticated approach using languagespecific classes, as discussed in Section 7.2. The match between this extremely simple measurement of language-specific similarity to the linguistically sophisticated similarity using language-specific classes is not as good as for the more elaborate algorithmic approach from the previous section ( $r=.61$, cf. Figure 4 with the previous Figure 3 ), though the correlation is still highly significant (Mantel test $p<.00001$ ), indicating that even with similarity measures which are linguistically very naive relatively good overall results are possible. 


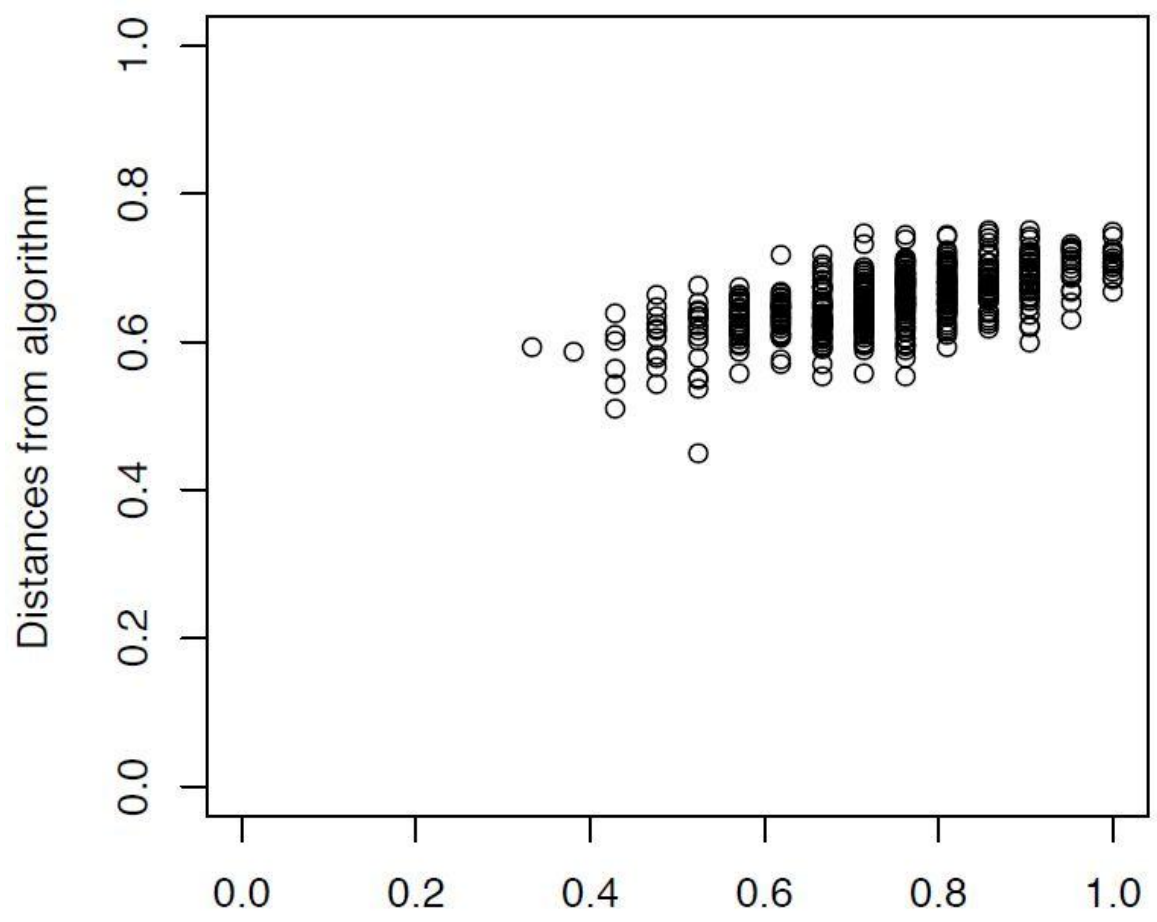

Distances from language-particular classes

Figure 4: Correlation between cross-linguistic distances as established by language-specific classes and by the longest common substring.

\section{Conclusion}

By using the world's linguistic diversity, the study of meaning can be transformed from an introspective inquiry into a subject of empirical investigation. For this to be possible, the notion of meaning has to be operationalized by defining the meaning of an expression as the collection of all contexts in which the expression can be used. Under this definition, meaning can be empirically investigated by sampling contexts. A semantic map is a technique to show the relations between such sampled contexts. Or, formulated more technically, a semantic map is a visualization of a metric on contexts sampled to represent a domain of meaning. Or, put more succinctly, a semantic map is a metric on meaning.

The relation between different contexts/meanings can be investigated by looking at their expressions in many languages. The more similar these expressions when averaged over all languages studied, the more similar the contexts. So, to investigate the similarity between contexts, only judgments about the local similarity between expressions within the structure of individual languages are needed. In general, this similarity between language-specific expressions is a special-language-specific - metric between contexts. A metric on meaning, then, is the cross-linguistic average of many language-specific expression metrics.

A language-specific expression metric can be very fine-grained, and to a large extent automatically retrieved, opening up the possibility of speeding up the empirical study of meaning. It is important to realize, however, that for any resulting semi-automatically retrieved metric on meaning, the interpretation ("the meaning of the metric") is of course still in the eye of the beholder, namely, the human investigator. 


\section{Acknowledgments}

I thank Martin Haspelmath and Caterina Mauri for helpful comments on how to improve the presentation of the somewhat tedious subject of this paper. Further, many of the concepts used in this paper arose in discussion with Bernhard Wälchli and should often just as well be considered his ideas (cf. Wälchli \& Cysouw 2010). I of course take complete responsibility for any remaining inconsistency or lack of clarity.

\section{References}

Comrie, Bernard and Tania Kuteva. 2005. Relativization strategies. World Atlas of Language Structures, ed. by Martin Haspelmath, Matthew S. Dryer, David Gil and Bernard Comrie, 398-405. Oxford: Oxford University Press.

Croft, William. 2001. Radical Construction Grammar: Syntactic theory in typological perspective. Oxford: Oxford University Press.

----. 2003. Typology and universals, 2nd edition. Cambridge: Cambridge University Press. (Cambridge Textbooks in Linguistics).

----. 2007. Exemplar semantics. Unpublished manuscript, available online at http://www.unm.edu/ wcroft/WACpubs.html.

Croft, William and Keith T. Poole. 2008. Inferring universals from grammatical variation: Multidimensional scaling for typological analysis. Theoretical Linguistics 34/1.1-37.

Cysouw, Michael. 2007. Building semantic maps: The case of person marking. New Challenges in Typology, ed. by Bernhard Wälchli and Matti Miestamo, 225-248. Berlin: Mouton de Gruyter. (Trends in Linguistics: Studies and Monographs 189).

-----. 2008. Generalizing scales. Scales, ed. by Marc Richards \& Andrej Malchukov, 379-396. Leipzig: Institut für Linguistik, Universität Leipzig. (Linguistische Arbeits-Berichte 86).

Dahl, Östen. 1985. Tense and Aspect systems. Oxford: Blackwell.

Goldberg, Adele E. 2006. Constructions at work: The nature of generalization in language. Oxford: Oxford University Press.

Haiman, John. 1985. Natural syntax. Cambridge: Cambridge University Press.

Haspelmath, Martin. 1993. More on the typology of inchoative/causative verb alternations. Causatives and transitivity, ed. by Bernard Comrie and Maria Polinsky, 87-120. Amsterdam: Benjamins. (Studies in Language Companion Series).

-----. 1997. Indefinite pronouns. Oxford: Clarendon. (Oxford Studies in Typology and Linguistic Theory).

-----. 2003. The geometry of grammatical meaning: Semantic maps and cross-linguistic comparison. The new psychology of language: Cognitive and functional approaches to language structure, ed. by Michael Tomasello, vol. 2, 211-242. Mahwah, NJ: Erlbaum.

-----. 2008. Comparative concepts and descriptive categories in cross-linguistic studies. Language 86 (forthcoming).

Keenan, Edward L. 1976. Towards a universal definition of 'subject'. Subject and topic, ed. by Charles N. Li, 303-333. New York, NY: Academic Press.

Keenan, Edward L. and Bernard Comrie. 1977. Noun phrase accessibility and universal grammar, Linguistic Inquiry 8/1.63-99.

Koptjevskaja-Tamm, Maria. 1993. Nominalizations. London: Routledge.

-----. 2005. Action nominal constructions. World Atlas of Language Structures, ed. by Martin 
Haspelmath, Matthew S. Dryer, David Gil and Bernard Comrie, 254-257. Oxford: Oxford University Press.

Lehmann, Christian. 1984. Der Relativsatz: Typologie seiner Strukturen, Theorie seiner Funktionen, Kompendium seiner Grammatik. Tübingen: Narr.

Levinson, Stephen C. 2003. Space in language and cognition: Explorations in cognitive diversity. Cambridge: Cambridge University Press. (Language, Culture \& Cognition 5).

Levinson, Stephen C. and Sérgio Meira. 2003. 'Natural concepts' in the spatial topological domain - Adpositional meanings in crosslinguistic perspective: An exercise in semantic typology. Language 79/3.485-516.

Majid, Asifa, Melissa Bowerman, Miriam van Staden and James S. Boster. 2007. The semantic categories of cutting and breaking events: A crosslinguistic perspective. Cognitive Linguistics 18/2.133-152.

R Development Core Team. 2007. R: A Language and Environment for Statistical Computing. Vienna, Austria: R Foundation for Statistical Computing.

Wälchli, Bernhard. 2005. Co-compounds and natural coordination. Oxford: Oxford University Press.

Wälchli, Bernhard and Michael Cysouw. 2008. Lexical typology through similarity semantics: Toward a semantic map of motion verbs. Linguistics (forthcoming).

Wierzbicka, Anna. 1996. Semantics: Primes and universals. Oxford: Oxford University Press.

Author's contact information:

Michael Cysouw

Department of Linguistics

Max Planck Institute for Evolutionary Anthropology

Deutscher Platz 6

04103 Leipzig

Germany

cysouw@eva.mpg.de 


\section{Appendix: Language-Specific Classes of Causative/Inchoative Alternations}

\section{Arabic}

\section{Class A: C/CC}

1. sahaa/sah́haa

8. darasa/darrasa

14. damara/dammara

31. waqafa/waqqafa

Class B: in/ø

2. inkasara/kasara

5. infatah́a/fatah́a

6. inqafala/qafala

13. inșahara/șahara

30. inšaqqa/šaqqa

Class C: in/?

3. ihtaraqa/Rahraqa

20. intafa?a/Rațfa?a

22. intahaa/Ranhaa

\section{Class D: $\mathrm{t} / ø$}

9. iltamma/lamma

10. intašara/našara

17. irtabața/rabața

21. irtafaSa/rafaia

27. imtala?a/mala?a

\section{Class E: $ø / ?$}

11. ġariqa/Ragraqa

18. galaa/Rağlaa

23. daara/Radaara

26. ðaaba/Raðaaba

Class F: ta/ø

12. tabaddala/baddala

16. tatawwara/tawwara

19. taใarjah̆/Rarjah́a

24. tadah́raja/dah́raja

25. tajammada/jammada

28. tah́assana/h́assana

\section{Singular classes:}

4. maata/qatala

7. bada?a

15. daaia/xasira

29. jaffa/jaffafa
Armenian

Class A: ø/c

1. artnanal/artnacnel

16. zarzanal/zarzacnel

21. barzranal/barzracnel

22. k'eršanal/k' eršacnel

28. lavanal/lavacnel

29. čoranal/čoracnel

Class B: v/ø

2. క̌ardvel/క̌ardel

3. ayrvel/ayrel

6. pak'vel/pak'el

7. sksvel/sksel

9. havakvel/havakel

10. ondarc'ak'vel/ondarc'ak'el

11. xegolvel/xegolel

12. poxvel/poxel

13. halvel/halel

14. kandvel/kandel

17. k'ap'vel/k'ap'el

19. č'oč'vel/č'oč'el

23. pttvel/pttel

24. glorvel/glorel

26. luc'vel/luc'el

30. č' eykvel/č'eykel

Class C: v/n

5. bacvel/bacanal

27. lcvel/lcnel

\section{Class D: ø/Vcn}

8. sovorel/sovorecnel

18. eral/eracnel

31. k'angnil/k'angnecnel

Class E: ̌̌/cn

15. k'orčel/k'orcnel

20. hangčel/hangcnel

25. sařrcel/sarecnel

Class F:

4. spanel/mernel

\section{English}

\section{Class A: Identical}

1. wake up

2. break

3. burn

$5 . \quad$ open

6. close

7. begin

9. gather

10. spread

11. sink

12. change

13. melt

16. develop

17. connect

18. boil

19. rock

22. finish

23. turn

24. roll

25. freeze

26. dissolve

27. fill

28. improve

29. dry

30. split

31. stop

Singular classes:

4. die/kill

8. learn/teach

14. be destroyed/destroy

15. get lost/lose

20. go out/put out

21. rise/raise 


\section{Finnish}

\section{Class A: $\varnothing / \mathrm{tt}$}

1. herätä/herättää

3. palaa/polttaa

8. oppia/opettaa

10. levitä/levittää

13. sulaa/sulattaa

18. kiehua/kiehuttaa

19. kiikkua/kiikuttaa

20. sammua/sammuttaa

21. kohota/kohottaa

22. loppua/lopettaa

24. vieriä/vierittää

26. liueta/liuottaa

29. kuivaa/kuivata

\section{Class B: U/ø}

2. murtua/murtaa

12. muuttua/muuttaa

16. kehittyä/kehittää

23. vääntyä/vääntää

27. täyttyä/täyttää

28. parantua/parantaa

\section{Class C: UtU/ø}

5. avautua/avata

6. sulkeutua/sulkea

14. tuhoutua/tuhota

\section{Class D: $\mathrm{ntu} / \mathrm{t}$}

9. kokoontua/koota

15. hukkaantua/hukata

\section{Class E: tyä/dytää}

17. yhtyä/yhdistää

25. jäätyä/jäädyttää

31. pysähtyä/pysähdyttää

\section{Singular classes:}

4. kuolla/tappaa

7. alkaa/aloitaa

11. laskea

30. haljeta/halkaista

\section{French}

\section{Class A: se/ø}

1. se réveiller/réveiller

2. se briser/briser

5. s'ouvrir/ouvrir

6. se fermer/fermer

9. s'assembler/assembler

10. s'étendre/étendre

11. s'enfoncer/enfoncer

15. se perdre/perdre

16. se développer/développer

17. se lier/lier

19. se balancer/balancer

20. s'éteindre/éteindre

21. se lever/lever

23. se tourner/tourner

26. se dissoudre/dissoudre

27. se remplir/remplir

28. s'améliorer/améliorer

30. se fendre/fendre

31. s'arrêter/arrêter

\section{Class B: Identical}

3. brûler

7. commencer

8. apprendre

12. changer

22. finir

24. rouler

25. geler

29. sécher

\section{Class C: ø/faire}

13. fondre/faire fondre

18. bouillir/faire bouillir

\section{Singular classes:}

4. mourir/tuer

14. être détruit/détruir

\section{Georgian}

Class A: i/a

1. gaiyvizebs/gaayvizebs

8. isc'avlis/asc'avlis

Class B: $i+a / a+s$

2. imt'vreva/amt'vrevs

5. gaizeba/gaayebs

11. daixrčoba/axrčobs

14. daingreva/daangrevs

19. irxeva/arxevs

27. aivseba/aavsebs

30. gaip'oba/gaap'obs

Class C: $\mathrm{i}+\mathrm{eba} / ø+$ avs

6. daixureba/daxuravs

15. ik'argeba/k'argavs

25. gaiqineba/gaqinavs

Class D: $\mathrm{i}+\mathrm{eba} / ø+\mathrm{is}$

9. šeik'ribeba/šek'rebs

12. šeicvleba/šecvlis

16. daišleba/dašlis

26. gaixsneba/gaxsnis

\section{Class E: $\varnothing+\mathrm{eba} / \mathrm{a}+\mathrm{obs}$}

13. gadneba/gaadnobs

20. kreba/akrobs

29. šreba/ašrobs

\section{Class F: $\varnothing+$ deba/a + ebs}

10. gavrceldeba/gaavrcelebs

22. gatavdeba/gaatavebs

28. gaumžobesdeba/ gaaumžobesebs

31. gačerdeba/gaačerebs

\section{Class G: $\varnothing+$ avs/a + ebs}

23. brunavs/abrunebs

24. migoravs/miagorebs

\section{Singular classes:}

3. ic'vis/c'vavs

4. mok'vdeba/mok'lavs

7. daic'qeba/daic'qebs

17. šeexameba/šeuxamebs

18. duys/aduyebs

21. adgeba/aiyebs 


\section{German}

\section{Class A: Identical}

2. zerbrechen

3. verbrennen

7. anfangen

13. schmelzen

18. kochen

19. schaukeln

24. rollen

25. einfrieren

29. trocknen

31. anhalten

\section{Class B: sich/ø}

5. sich öffnen/öffnen

6. sich schliessen/schliessen

9. sich sammeln/sammeln

10. sich ausbreiten/ausbreiten

12. sich verändern/verändern

16. sich entwickeln/entwickeln

17. sich verbinden/verbinden

21. sich heben/heben

23. sich umdrehen/umdrehen

26. sich auflösen/auflösen

27. sich füllen/füllen

28. sich verbessern/verbessern

30. sich spalten/spalten

\section{Singular classes:}

1. aufwachen/aufwecken

4. sterben/töten

8. lernen/lehren

11. versinken/versenken

14. kaputt gehen/kaputt machen

15. verloren gehen/verlieren

20. erlöschen/löschen

22. enden/beenden

\section{Greek}

\section{Class A: Identical}

1. ksipnó

2. spázo

5. anígho

6. klíno

7. arçízo

8. mathéno

12. alázo

14. xalnó

18. vrázo

20. svíno

22. telióno

23. yirízo

25. paghóno

27. yemízo

30. xorízo

31. stamatáo

\section{Class B: me/ø}

3. kéome/kéo

9. singendrónome/ singendróno

10. dhiadhídhome/dhiadhídho

11. vithízome/vithízo

13. tíkome/tíko

15. xánome/xáno

16. anaptísome/anaptíso

17. sindhéome/sindhéo

19. liknízome/liknízo

21. sikónome/sikóno

24. kiliéme/kilió

26. dhialíome/dhialío

28. veltiónome/veltióno

29. apoksirénome/apoksiréno

\section{Singular classes:}

4. pethéno/skotóno

\section{Hebrew}

\section{Class A: hit/ø}

1. hitforer/forer

9. hit?asef/?asaf

10. hitpares/paras

12. hištana/šina

16. hitpatah/patah

17. hitkašer/kišer

19. hitnadned/nidned

21. hitromem/romem

23. histovev/sovev

26. hitporer/porer

27. hitmale/mile

28. hištaper/šiper

29. hityabeš/yibeš

30. hitpacel/picel

\section{Class B: ni/ø}

2. nišbar/šavar

3. nisraf/saraf

5. niftah́/patah́

6. nisgar/sagar

22. nigmar/gamar

31. nefecar/facar

\section{Class C: $ø / \mathrm{hV}$}

4. mat/hemit

14. harav/heh́eriv

18. ratah́/hirtiah́

25. kafa/hikfi

Class D: av/ib

11. tavai/tibai

15. Pavad/Ribed

20. kava/kiba

\section{Singular classes:}

7. hithil

8. lamad/limed

13. namas/hemes

24. nagol/galal 


\section{Hindi-Urdu}

Class A: ø/aa

1. jaagnaa/jagaanaa

3. jalnaa/jalaanaa

8. parhnaa/parhaanaa

10. phailnaa/phailaanaa

13. pighalnaa/pighlaanaa

19. hilnaa/hilaanaa

21. uthnaa/uthaanaa

23. phirnaa/phiraanaa

24. luṛhaknaa/luṛkaanaa

25. jamnaa/jamaanaa

26. ghulnaa/ghulaanaa

29. suukhnaa/sukhaanaa

Class B: $\mathbf{t} / \mathbf{r}$

2. țuuṭaa/țornaa

30. phaṭaa/phaarnaa

\section{Class C: a/aa}

4. marnaa/maarnaa

14. ujarnaa/ujaarnaa

17. bandhnaa/baandhnaa

18. ubalnaa/ubaalnaa

Class D: u/o

5. khulnaa/kholnaa

31. ruknaa/roknaa

Class E: honaa/karnaa

6. band honaa/band karnaa

7. šuruu honaa/šuruu karnaa

9. ikatthaa honaa/ ikatthaa karnaa

16. vikaas honaa/vikaas karnaa

20. gul honaa/gul karnaa

22. xatm honaa/xatm karnaa

28. behtar honaa/behtar banaanaa

Class F: Identical

12. badalnaa

27. bharnaa

\section{Singular classes:}

11. ḍubnaa/ḍubonaa

15. khojaanaa/khonaa
Hungarian

Class A: $d /$ szt

1. felébred/felébreszt

10. terjed/terjeszt

11. elsüllyed/elsüllyeszt

13. olvad/olvaszt

Class B: $ø / \mathrm{Vt}$

3. elég/eléget

15. elvész/elveszít

23. forog/forgat

31. megáll/megállít

\section{Class C: Vlik/it}

5. kinyílik/kinyit

9. összegyülik/összegyüjt

\section{Class D: Odik/ø}

6. záródik/zár

7. elkezdödik/elkezd

22. befejezödik/befejez

26. oldódik/old

Class E: Ul/it

8. tanul/tanít

14. elpusztul/elpusztít

24. gurul/gurít

28. javul/javít

Class F: ik/tat

12. megváltozik/megváltoztat

19. hintázik/hintáztat;

Class G: ad/it

29. szárad/szárít

30. széthasad/széthasít

\section{Singular classes:}

2. összetörik/összetör

4. meghal/megöl

16. fejlödik/fejleszt

17. szövetkezik/összeköt

18. fö/föz

20. kialszik/kiolt

21. emelkedik/emel

25. megfagy/megfagyaszt

27. megtelik/tölt
Indonesian

Class A: ter/me+kan

1. terbangun/membangunkan

10. tersebar/menyebarkan

Class B: $\varnothing / \mathrm{me}+\mathrm{kan}$

2. patah/mematahkan

4. mati/mematikan

11. tenggelam/menenggelamkan

14. binasa/membinasakan

20. padam/memadamkan

22. selesai/menyelesaikan

26. larut/melarutkan

29. kering/mengeringkan

Class C: ter/me

3. terbakar/membakar

5. terbuka/membuka

27. terisi/mengisi

30. terbelah/membelah

Class D: $ø / \mathrm{me}$

6. tutup/menutup

7. mulai/memulai

Class E: ber/meng

8. belajar/mengajar

12. berubah/mengubah

19. berayun/mengayun

Class F: ø/kan

9. mengumpul/mengumpulkan

13. mencair/mencairkan

24. menggelinding/menggelindingkan

25. membeku/membekukan

Class G: ber/me + kan

16. berkembang/ mengembangkan

17. bergabung/menggabungkan

23. berbalik/membalikkan

31. berhenti/menghentikan

\section{Singular classes:}

15. menghilang/kehilangan

18. direbus/merebus

21. kenaikan/menaikkan

28. bertambahbaik/ memperbaiki 
Japanese

\section{Class A: $\mathrm{Vr} / \mathrm{Vs}$}

1. okiru/okosu

6. toziru/tozasu

13. tokeru/tokasu

19. yureru/yurasu

20. kieru/kesu

23. mawaru/mawasu

24. korogaru/korogasu

26. tokeru/tokasu

27. mitiru/mitasu

28. naoru/naosu

\section{Class B: er/ø}

2. oreru/oru

3. yakeru/yaku

30. sakeru/saku

\section{Class C: ø/er}

5. aku/akeru

11. sizumu/sizumeru

\section{Class D: a/e}

7. hazimaru/hazimeru

8. osowaru/osieru

9. atumaru/atumeru

10. hirogaru/hirogeru

12. kawaru/kaeru

17. tunagaru/tunageru

21. agaru/ageru

22. owaru/oeru

31. tomaru/tomeru

Class E: ø/ase

16. hattatu suru/ hattatu saseru

25. kooru/kooraseru

\section{Class F: ø/as}

18. waku/wakasu

29. kawaku/kawakasu

\section{Singular classes:}

4. $\operatorname{sinu} /$ korosu

14. kowareru/kowasu

15. nakunaru/nakusu

\section{Lezgian}

\section{Class A: Identical}

2. xun

3. kun

4. q'in

18. rugun

30. xun

\section{Class B: $\hat{\mathbf{x}} / \varnothing$}

5. aq $^{\text {ha }} \hat{x} u n / q^{\text {hajun }}$

6. k'ew x̂u/k'ewun

7. bašlamiš x̂un/bašlamišun

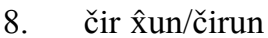

9. k'wat' $\hat{x} u n / k^{\prime} w a t ' u n$

19. e'čä x̂un/e'čăğun

21. xkaž x̂un/xkažun

22. kütäh x̂un/kütähun

\section{Class C: $ø / \mathbf{r}$}

10. čuk'un/čuk'urun

13. c'urun/c'ururun

14. čuk'un/čuk'urun

17. sadsadaw q'un/sadsadaw q'urun

20. tüxün/tüxürun

23. elqün/elqürun

25. č'agun/č'agurun

26. c'urun/c'ururun

27. ac'un/ac'urun

29. q'urun/q'ururun

\section{Class D: $\hat{x} / a r$}

11. batmiš x̂un/batmišarun

12. degiš x̂un/degišarun

28. $\mathrm{q}^{\mathrm{h}} \operatorname{san} \hat{\mathrm{x} u n} / \mathrm{q}^{\mathrm{h}}$ sanarun

\section{Class E: ø/ar}

15. kwax̂u/kwadarun

31. aqwazun/aqwazarun

\section{Class F: fin/raqurun}

16. wilik fin/wilik raqurun

24. awax̂izawax̂iz fin/awax̂izawax̂iz raqurun

\section{Class D: $\mathrm{t} / \mathrm{d}$}

1. axwaraj awatun/ axwaraj awudun

\section{Lithuanian}

\section{Class A: ø/in}

1. pabusti/pabudinti

3. degti/deginti

11. skendeti/skandinti

18. virti/virinti

20. gesti/gesinti

26. ištirpti/ištirpinti

28. gerèti/gerinti

29. sausti/sausinti

Class B: ūp/au

2. lūžti/laužti

14. sugriūti/sugriauti

31. nutrūkti/nutraukti

\section{Class C: si/ø}

5. atsidaryti/atidaryti

7. prasideti/pradèti

10. išsiplèsti/išplèsti

12. pasikeisti/pakeisti

13. išsilydyti/išlydyti

15. pasimesti/pamesti

22. pasibaigti/pabaigti

27. prisipildyti/pripildyti

\section{Class D: s/ø}

6. klostytis/klostyti

8. mokytis/mokyti

9. rinktis/rinkti

16. plètotis/plètoti

17. jungtis/jungti

19. suptis/supti

23. suktis/sukti

24. ristis/risti

Class E: i/e

21. pakilti/pakelti

30. perskilti/perskelti

\section{Singular classes:}

4. užmušti/mirti

25. užšalti/užšaldyti 


\section{Mongolian}

\section{Class A: $ø / \mathrm{V}$}

1. serex/sereex

3. šatax/šataax

20. untrax/untraax

25. xöldöx/xöldööx

29. xatax/xataax

31. zogsox/zogsoox

Class B: $\mathbf{r} / \mathbf{l}$

2. xugarax/xugalax

30. xagarax/xagalax

\section{Class C: Vgd/ø}

6. xaagdax/xaax

12. öörčlögdöx/öörčlöx

15. xajagdax/xajax

17. xolbogdox/xolbox

21. ̈rgögdöx/örgöx

\section{Class D: $ø / g$}

7. üüsex/üüsgex

8. surax/surgax

18. buclax/bucalgax

22. duusax/duusgax

26. uusax/uusgax

27. düürex/düürgex

\section{Class E: ø/UU1}

9. cuglax/cugluulax

11. živex/živuulex

13. xajlax/xajluulax

16. xögžix/xögžüülex

19. dajvalzax/dajvalzuulax

23. ergex/ergüülex

24. önxröx/önxrüülex

28. sajžrax/sajžruulax

\section{Romanian}

Class A: se/ø

1. se trezi/trezi

2. se rupe/rupe

5. se deschide/deschide

6. se închide/închide

9. se aduna/aduna

10. se răspîndi/răspîndi

11. se scufunda/scufunda

12. se schimba/schimba

13. se topi/topi

15. se pierde/pierde

16. se dezvolta/dezvolta

17. se uni/uni

19. se legăna/legăna

20. se stinge/stinge

21. se ridica/ridica

22. se sfîrşi/sfîrşi

23. se învîrti/învîrti

24. se rostogoli/rostogoli

26. se dizolva/dizolva

27. se umple/umple

28. se îndrepta/îndrepta

29. se usca/usca

30. se crăpa/crăpa

31. se opri/opri

\section{Class B: Identical}

3. arde

7. începe

18. fierne

\section{Singular classes:}

4. muri/ucide

8. învăţa/preda

14. ?/distruge

25. îngheţa/face sa înghețe

\section{Russian}

\section{Class A: sja/ø}

2. lomat'sja/lomat'

5. otkryt'sja/otkryt'

6. zakryt'sja/zakryt'

7. načat'sja/načat'

8. učit'sja/učit'

9. sobrat'sja/sobrat'

10. rasprostranit'sja/ rasprostranit'

12. izmenit'sja/izmenit'

13. rasplavit'sja/rasplavit'

14. razručit'sja/razručit'

15. terjat'sja/terjat'

16. razvit'sja/razvit'

17. sočetat'sja/sočetat'

19. kačat'sja/kačat'

21. podnjat'sja/podnjat'

22. končit'sja/končit'

23. povernut'sja/povernut'

24. katit'sja/katit'

26. rastvorit'sja/rastvorit'

27. napolnit'sja/napolnit'

28. ulučšit'sja/ulučšit'

30. raskolot'sja/raskolot'

31. ostanovit'sja/ostanovit'

\section{Class B: nut/it}

11. utonut'/utopit'

20. gasnut'/gasit'

25. zamerznut'/zamorozit'

29. soxnut'/sušit'

\section{Singular classes:}

1. prosnut'sja/budit'

3. goret'/žeč'

4. umeret'/ubit'

18. kipet'/kipjatit'

\section{Class F: r/ø}

10. delgerex/delgex

14. evdrex/evdex

Singular classes:

4. üxex/alax

5. ongojx/ongojlgox 


\section{Swahili}

\section{Class A: $\mathrm{k} / \mathrm{sh}$}

1. amka/amsha

13. yeyuka/yeyusha

18. chemka/chemsha

24. fingirika/fingirisha

26. yeyuka/yeyusha

29. kauka/kausha

\section{Class B: $\mathbf{k} / ø$}

2. vunjika/vunja

3. unguka/ungua

5. funguka/fungua

9. kusanyika/kusanya

14. haribika/haribu

20. zimika/zima

21. inuka/inua

22. malizika/maliza

12. geuka/geua

30. pasuka/pasua

\section{Class C: w/ø}

6. fungwa/funga

17. ungwa/unga

\section{Class D: $ø /$ sh}

7. anza/anzisha

8. funda/fundisha

11. zama/zamisha

16. sitawia/sitawisha

19. yonga/yongesha

23. zungua/zungusha

25. ganda/gandisha

31. simama/simamisha

\section{Class E: $ø / z$}

10. enea/eneza

15. potea/poteza

27. jaa/jaza

\section{Singular classes:}

4. fa/ua

28. fanya ujambo/ pata ujambo

\section{Turkish}

\section{Class A: $ø / d V r$}

1. uyanmak/uyandırmak

4. ölmek/öldürmek

20. sönmek/söndürmek

21. kalkmak/kaldırmak

23. dönmek/döndürmek

25. donmak/dondurmak

27. dolmak/doldurmak

31. durmak/durdurmak

\section{Class B: V1/ø}

2. kırılmak/kırmak

5. açılmak/açmak

10. yayılmak/yaymak

14. bozulmak/bozmak

26. çözülmek/çözmek

\section{Class C: $\mathbf{n} / ø$}

9. toplanmak/toplamak

19. sallanmak/sallamak

24. yuvarlanmak/yuvarlamak

Class D: $\mathbf{n} / \mathbf{t}$

6. kapanmak/kapatmak

8. öğrenmek/öğretmek

\section{Class E: ø/tir}

16. inkişaf etmek/ inkişaf ettirmek

12. degişmek/degiştirmek

17. birleşmek/birleştirmek

\section{Class F: ø/ir}

11. batmak/batırmak

18. pişmek/pişirmek

22. bitmek/bitirmek

\section{Class G: ø/t}

13. erimek/eritmek

28. düzelmek/düzeltmek

29. kurumak/kurutmak

30. çatlamak/çatlatmak

\section{Singular classes:}

3. yanmak/yakmak

7. ?/başlamak

15. kaybolmak/kaybetmek

\section{Udmurt}

\section{Class A: ø/ty}

1. sajkany/sajkatyny

8. dyšyny/dyšetyny

10. võlmyny/võlmytyny

11 . vyjyny/vyjytyny

13. ćyžany/ćyžatyny

14. kuaškany/kuaškatyny

15. ysyny/ystyny

23. bergany/bergatyny

26. sylmyny/sylmytyny

27. tyrmyny/tyrmytyny

31. dugdyny/dugdytyny

Class B: śky/ø

2. tijaśkyny/tijany

3. sutskyny/sutyny

5. ustiśkyny/ustyny

6. pytsaśkyny/pytsany

9. l'ukaśkyny/l'ukany

12. voštiśkyny/voštyny

17. gerźaskyny/gerźany

19. vettaśkyny/vettany

21. 3̌utśkyny/žutyny

30. pil'iśkyny/pil'yny

\section{Class C: Identical}

7. kutskyny

18. byrektyny

20. kysyny

\section{Class D: sky/ty}

16. azinskyny/azintyny

24. pityrskyny/pityrtyny

28. umojatskyny/umojatyny

Class E: my/ty

22. bydesmyny/bydestyny

25 . kynmyny/kyntyny

29. kuasmyny/kuastyny

Class F:

4. kulyny/viyn 